УДК 638.1:003:638.19

(C) 2012

Ємець К. І., старший науковий співробітник

Національний науковий центр «Інститут бджільництва ім. П. І. Прокоповича»

\title{
ОЦІНКА ЗАБЕЗПЕЧЕНОСТІ БДЖОЛИНИМИ СІМ'ЯМИ ПОВНОЦІННОГО ЗАПИЛЕННЯ ОСНОВНИХ ЕНТОМОФІЛЬНИХ КУЛЬТУР
}

\author{
Рецензент - кандидат сільськогосподарських наук М. О. Шамро
}

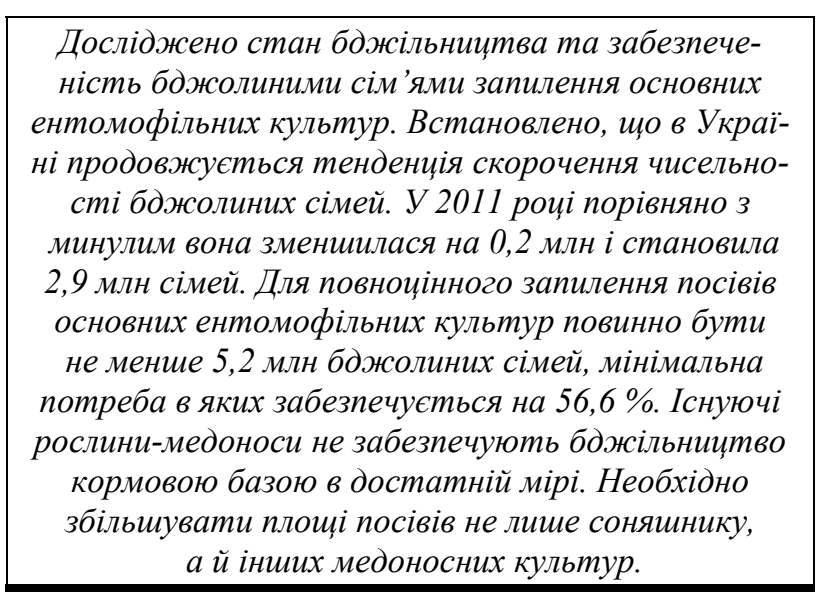

Ключові слова: бджільництво, чисельність бджслиних сімей, кормова база, запилення, ентомофільні культури, забезпеченість.

Постановка проблеми. Актуальність проблеми підвищення ефективності розвитку галузі бджільництва визначається зростаючою значимістю іiі продуктів для харчування й лікування населення, покращенням постачання промисловості сировиною, використанням бджіл для запилення ентомофільних сільськогосподарських культур. Без бджіл не можна отримати повноцінний врожай від $80 \%$ сільськогосподарських культур.

Згідно з гіпотезою, основою збільшення виробництва продукції бджільництва та запилення сільськогосподарських культур $\epsilon$ збільшення чисельності бджолиних сімей. Чи є це доцільним за наявної кормової бази для бджіл в Україні? Тому проведення досліджень, спрямованих на вивчення вказаних питань, $є$ достатньо актуальними як у сфері наукових досліджень, так і в господарській практиці.

Аналіз основних досліджень і публікацій, у яких започатковано розв'язання проблеми. Вивченням пріоритетних напрямів, що дають змогу тримати бджільництво на рентабельному рівні, факторів підвищення конкурентоздатності галузі займалися науковці нашого Національного наукового центру «Інститут бджільництва ім. П. І. Прокоповича», інших закладів, зокрема: Л. І. Боднарчук, С. І. Бугера, Є. В. Руденко, С. А. Чехов, О. М. Яценко, Д. Б. Жученко та інші [1-6]. Однак сучасний стан галузі бджільництва науковцями не досліджений.

За різними літературними даними, в Україні налічується від 2,8 до 3,5 млн бджолиних сімей. Згідно 3 програмою розвитку галузі бджільництва до 2015 року, необхідно наростити чисельність бджолиних сімей до 5 мільйонів.

Медоносні ресурси України досліджували науковці Української дослідної станції бджільництва (В. М. Блонська, Г. П. Блажієвська, О. О. Срастов), але така робота виконувалася 30 років тому й не пов'язувалася 3 наявною кількістю бджолиних сімей. У даний час змінилася структура медоносів, а відповідно, й їх цукрозапас.

Мета і завдання досліджень. Мета роботи вивчити концентрацію бджолиних сімей і забезпеченість ними повноцінного запилення основних ентомофільних сільськогосподарських культур.

Завдання досліджень - встановити наявну чисельність бджолиних сімей у цілому по Україні та в розрізі областей по всіх категоріях господарств; порівняти отримані дані з минулорічними показниками; встановити забезпеченість бджолиних сімей кормовою базою та провести розрахунок забезпеченості бджолиними сім'ями посівів основних ентомофільних сільськогосподарських культур для їх повноцінного запилення.

Матеріали і методи досліджень. Вихідними матеріалами для досліджень і розрахунків стали дані Держкомстату України, існуюча нормативно-технічна документація з бджільництва, літературні джерела.

Методом статистичної вибірки зібрані дані про чисельність бджолиних сімей і площі посівів ентомофільних сільськогосподарських культур й інших медоносів у розрізі областей України та господарств Гадяцького району Полтавської області.

Для визначення забезпеченості бджолиних сімей кормовою базою використовували дані про 
середню кількість цукру в нектарі одного гектару посіву. При встановленні забезпеченості бджолиними сім'ями повноцінного запилення ентомофільних сільськогосподарських культур користувалися нормами постановки сімей для запилення одного гектару їх посіву.

Досліджувані показники визначали розрахунковим шляхом.

Результати досліджень. Найбільша чисельність бджолиних сімей (б. с.) в Україні, починаючи 3 1987 року, була в 1991 р. - 3,5 мільйони. У наступні роки їх кількість зменшувалась і на початок 2011 р. становила 2,9 млн б. с., із них у господарствах населення - 96,7 \%. Для більшої переконливості наявність бджолосімей у всіх категоріях господарств України відображена за допомогою накопичувального графіка (див. рис.).

Встановлено, що кількість бджолиних сімей у сільськогосподарських підприємствах скоротилася по всіх областях у десять і навіть більше разів, по господарствах населення - збільшилася, хоча це збільшення не перекриває попереднє скорочення. Так, за 20 років (1991-2011 рр.) у підприємствах АПК бджолосімей стало менше на 892,4 тис., у населення їх збільшилося лише на 298,8 тисячі. Різниця становить 593,6 тис. бджолиних сімей. Найбільше сімей у 2011 році знаходилося в Донецькій і Хмельницькій областях, відповідно, 263,7 і 262,1 тисячі. Доречно зауважити, що в Хмельницькій області, на відміну від інших областей, за 20 років чисельність сімей значно зросла (на 146,4 тис. б. с.) за рахунок господарств населення.

Загальна чисельність бджолосімей у Полтавській області в 2011 р. - 161,5 тис., що менше, порівняно 32010 р., на 26,6 тисячі. У всіх категоріях господарств Гадяцького району нараховується 5578 б. с., із них у господарствах населення - 88,1 \%, у сільськогосподарських підприємствах - 11,9 \%, тоді як у 2001 р. цей показник, відповідно, становив 56,4 та 43,6 \%. Значний відсоток сімей у сільськогосподарських підприємствах району на той час - результат існування бджолооб'єднання.

По Гадяцькому району 77,2 \% пасік налічують до 20 б. с., що становить 36,2 \% від загальної кількості сімей. Понад 50 б. с. утримуються на 6,6 \% пасік, тобто 34,4 \% від числа всіх сімей. У середньому на приватне пасічницьке господарство району припадає 20 б. с., але в більшості населення утримує пасіки, що налічують 5 б. с. $(28,6 \%)$.

Основою кормової бази для бджіл є ентомофільні сільськогосподарські культури, лісові та плодово-ягідні насадження, лугове різнотрав'я.

В Україні з посіяних ентомофільних культур найбільші площі займають соняшник і гречка.

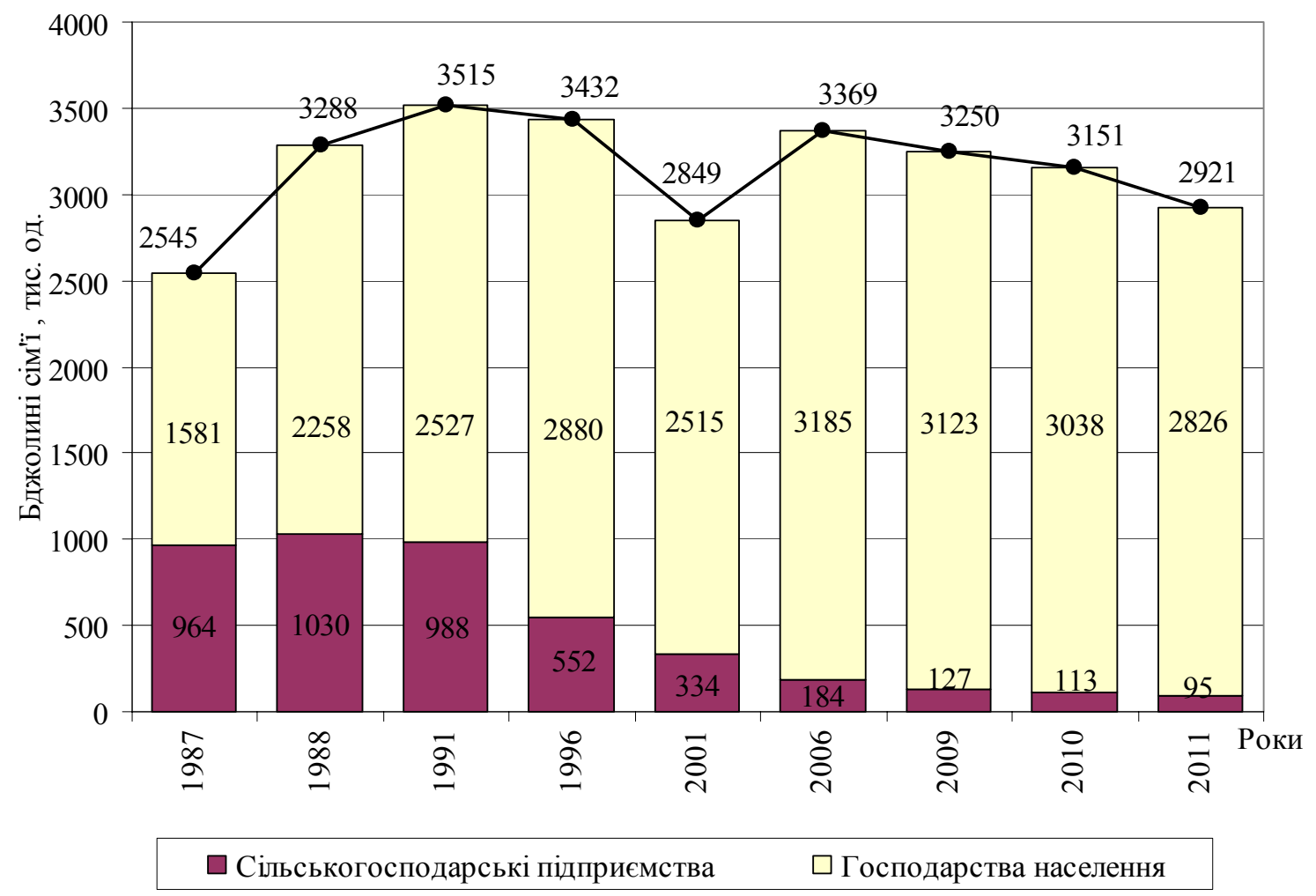

Рис. Наявність бджолосімей у всіх категоріях господарств Украӥни 
Починаючи з 1990 р., посіви соняшнику збільшували 3 кожним роком по всіх областях, $і$ до 2011 р. вцілому по країні вони становили 4558,3 тис. га, тобто площа зросла в 2,8 разу. Площа посіву гречки, навпаки, зменшувалась і в 2010 р. була найменшою - лише 198,5 тис. гектарів. У 2011 р. гречки посіяно 303,2 тис. га, найбільша ії площа була в 2000 і 2001 pp. (529,2 і 576,8 тис. га). Останнім часом став розповсю- дженішим ріпак, площа якого зросла в десять разів. Плодово-ягідних насаджень в Україні зменшилося втричі (табл. 1).

Доступний для бджіл цукрозапас вказаних культур у 2011 році становив: соняшнику 34,5 кг; гречки - 2,7; ріпаку - 4,5; плодовоягідних насаджень - 0,8 кг у розрахунку на одну бджолину сім'ю.

1. Основні ентомофільні культури по всіх категоріях господарств Украӥни, тис. га

\begin{tabular}{|c|c|c|c|c|}
\hline Рік & Гречка & Соняшник & Ріпак & $\begin{array}{c}\text { Плодово-ягідні } \\
\text { насадження }\end{array}$ \\
\hline 1990 & 350,5 & 1626,3 & 89,6 & 679,8 \\
\hline 1995 & 447,7 & 2007,6 & 46,9 & 636,9 \\
\hline 2000 & 529,2 & 2841,6 & 156,7 & 378,0 \\
\hline 2005 & 396,2 & 3689,1 & 195,2 & 265,5 \\
\hline 2008 & 282,0 & 4279,5 & 1379,6 & 233,4 \\
\hline 2009 & 254,3 & 4193,0 & 1013,7 & 228,8 \\
\hline 2010 & 198,5 & 4525,8 & 862,5 & 223,2 \\
\hline 2011 & 303,2 & 4558,3 & 872,2 & 223,2 \\
\hline
\end{tabular}

Джерело: Держкомстат України

2. Забезпеченість бджолиними сім'ями посівів ентомофільних сільськогосподарських культур у 2011 році

\begin{tabular}{|c|c|c|c|c|c|}
\hline \multirow[b]{2}{*}{ Області } & \multirow{2}{*}{$\begin{array}{l}\text { Наявність б. с. у всіх } \\
\text { категоріях госпо- } \\
\text { дарств, тис. сімей }\end{array}$} & \multicolumn{2}{|c|}{ Площа посіву, тис. га } & \multirow{2}{*}{$\begin{array}{l}\text { Мінімальна по- } \\
\text { треба для запи- } \\
\text { лення, тис. б. с. }\end{array}$} & \multirow{2}{*}{$\begin{array}{l}\text { Забезпече- } \\
\text { ність, \% }\end{array}$} \\
\hline & & соняшник & гречка & & \\
\hline АР Крим & 117,8 & 53,7 & & 53,7 & 219,4 \\
\hline Вінницька & 193,2 & 148,8 & 25,9 & 200,6 & 96,3 \\
\hline Волинська & 26,3 & 1,2 & 3,2 & 7,6 & 346,1 \\
\hline Дніпропетровська & 142,5 & 456,7 & 11,7 & 480,1 & 29,7 \\
\hline Донецька & 263,7 & 417,2 & 9,3 & 435,8 & 60,5 \\
\hline Житомирська & 156,0 & 33,4 & 10,6 & 54,6 & 285,7 \\
\hline Закарпатська & 67,3 & 2,8 & 0,4 & 3,6 & 1869,4 \\
\hline Запорізька & 114,7 & 580,8 & 2,0 & 584,8 & 19,6 \\
\hline Івано-Франківська & 147,2 & 5,6 & 4,6 & 14,8 & 994,6 \\
\hline Київська & 51,8 & 87,2 & 19,2 & 125,6 & 41,2 \\
\hline Кіровоградська & 120,9 & 458,7 & 20,1 & 498,9 & 24,2 \\
\hline Луганська & 67,1 & 351,8 & 6,2 & 364,2 & 18,4 \\
\hline Львівська & 65,1 & 1,2 & 7,9 & 17,0 & 382,9 \\
\hline Миколаївська & 153,4 & 347,3 & 10,9 & 369,1 & 41,6 \\
\hline Одеська & 119,5 & 295,7 & 4,2 & 304,1 & 39,3 \\
\hline Полтавська & 161,5 & 234,1 & 18,7 & 271,5 & 59,5 \\
\hline Рівненська & 51,6 & 3,1 & 5,9 & 14,9 & 346,3 \\
\hline Сумська & 121,0 & 116,1 & 27,3 & 170,7 & 70,9 \\
\hline Тернопільська & 59,3 & 13,5 & 20,0 & 53,5 & 110,8 \\
\hline Харківська & 128,8 & 364,1 & 25,8 & 415,7 & 31,0 \\
\hline Херсонська & 55,8 & 309,3 & 1,3 & 311,9 & 17,9 \\
\hline Хмельницька & 262,1 & 35,8 & 34,4 & 104,6 & 59,4 \\
\hline Черкаська & 136,8 & 158,0 & 12,5 & 183,0 & 74,8 \\
\hline Чернівецька & 83,0 & 7,1 & 0,9 & 8,9 & 932,6 \\
\hline Чернігівська & 55,1 & 75,3 & 20,1 & 115,5 & 47,7 \\
\hline Всього по Україні & 2921,5 & 4558,3 & 303,2 & 5164,7 & 56,6 \\
\hline Гадяцький район & 5,6 & 12,1 & 2,0 & 16,1 & 34,8 \\
\hline
\end{tabular}


Детально вивчивши медоносні угіддя на прикладі одного району, а саме Гадяцького району Полтавської області, встановлено, що із загального цукрозапасу всіх медоносів на частку ентомофільних сільськогосподарських культур припадає 79,8 \%, плодово-ягідних насаджень - 0,3, лук і пасовищ - 12,3 та лісових насаджень $7,6 \%$. У районі в розрахунку на одну бджолину сім'ю є 142,6 кг біологічного цукрозапасу. За даними науковців, бджоли можуть продуктивно використати близько $50 \%$ нектарного запасу місцевості. Отже, доступний для бджіл цукрозапас медоносів становить 71,3 кг, а медова продуктивність угідь - 89,1 кг на одну сім'ю.

У середньому за рік кожна бджолина сім'я витрачає 70-90 кг корму для своєї життєдіяльності. Виходить, що нинішні природні медозбірні умови району можуть забезпечити лише існування бджіл, а щоб отримати товарний мед, то його обсяг (кількість викачаного меду) потрібно компенсувати іншими кормами, наприклад, цукровим сиропом.

Із проведених розрахунків видно, що наявна кормова база не задовольняє бджільництво в достатній мірі. Це означає, що бджолиних сімей у районі потрібно утримувати менше або висівати більше ентомофільних сільськогосподарських культур, але висновки, що випливають із інших розрахунків, $є$ прямою протилежністю першим.

Розрахунок забезпеченості бджолиними сім'ями посівів основних ентомофільних сільськогосподарських культур (соняшнику й гречки, бо квітують вони в основному в один період) для повноцінного їх запилення показав, що мінімальна потреба бджолосімей для вказаних цілей у 2011 році забезпечувалася по Гадяцькому району лише на $34,8 \%$, у цілому по Україні - на $56,6 \%$. У розрізі областей насиченість бджолосім'ями посівів соняшнику й гречки досить різниться. Найбільше сімей на 1 га посівів припадає

\section{БІБЛІОГРАФІЯ}

1. Боднарчук Л. І. Спеціалізація і концентрація виробництва / Л. І. Боднарчук, К. І. Смець, Л. Л. Дудка // Пасіка. - 2008. - №12. - С. 2-3.

2. Бугера C. I. Промислове бджільництво: організаційно-правовий аспект / С. I. Бугера // Пасіка. - 2009. - №4. - С. 2-3.

3. Жученко Д. Б. Шляхи підвищення ефективності пасічного господарства / Д. Б. Жученко, В. С. Уланчук // Економіка АПК. - 2009. - №7. C. $50-55$.

4. Руденко С. В. Основні напрями та шляхи розвитку бджільництва / Є. В. Руденко, І. Г. Маслій, на західні області України, найменше - на південні та центральні (табл. 2).

Для повноцінного запилення посівів основних ентомофільних культур в Україні повинно бути не менше 5,2 млн бджолиних сімей. За статистичними даними, їх чисельність становить 2,9 мільйонів.

Для нормального функціонування бджолиних сімей та одержання від їх утримання прибутку в Україні повинні збільшувати площі посіву не лише соняшнику, а й інших медоносних культур: еспарцету, люцерни, буркуну, спеціальних медоносів тощо. Однак вказані рослини висіваються для потреб скотарства, яке останнім часом знаходиться на межі знищення (занедбане або й взагалі відсутнє), і тому площі посівів таких кормових культур вкрай малі.

Висновки. В Україні продовжується тенденція скорочення чисельності бджолиних сімей. У 2011 р. залишилося 2,9 млн сімей, хоча для повноцінного запилення посівів основних ентомофільних культур їх повинно бути не менше 5,2 мільйонів. Мінімальна потреба в бджолосім'ях по країні забезпечується на 56,6 \%, по Гадяцькому району - лише на $34,8 \%$.

На частку ентомофільних сільськогосподарських культур припадає 79,8 \% загального цукрозапасу всіх медоносів. У цілому по країні доступний для бджіл цукрозапас соняшнику становить 34,5 кг, гречки - 2,7 і ріпаку - 4,5 кг на одну бджолосім'ю. В Україні існує необхідність збільшення площі посівів не лише соняшнику, а й інших медоносних культур для забезпечення бджолиних сімей кормовою базою в достатній мірі.

Держава повинна сприяти інтенсифікації галузі бджільництва, поскільки від ії стану залежить розвиток рослинництва й, відповідно, продовольча безпека країни та виробництво натуральних продуктів бджільництва, необхідних для оздоровлення населення країни.

С. М. Нємцова // Вісник аграрної науки. 2006. - №5. - C. 40-42.

5. Чехов С. А. Формування і функціонування ринку продукції бджільництва в Україні : Автореферат дис. ... канд. екон. наук / С. А. Чехов // Ін-т аграрної економіки УААН. - К., 2002. - 19 с. 6. Яченко О. М. Зовнішня торгівля продукцією бджільництва України / О. М. Яценко // Матеріали XVII Міжнародного конгресу Федерації бджолярських організацій країн центральної і східної Європи - Апіславії. - К., 2009. - С. 49-56. 